\title{
Full Steam Ahead for PV in US Homes?
}

\section{Mark Bolinger, Galen Barbose, and Ryan Wiser (Lawrence Berkeley National Laboratory)}

In October 2008, the United States Congress extended both the residential and commercial solar investment tax credits (ITCs) for an unprecedented eight years, lifted the $\$ 2,000$ cap on the residential credit, removed the prohibition on utility use of the commercial credit, and eliminated restrictions on the use of both credits in conjunction with the Alternative Minimum Tax. These significant changes, which apply to systems placed in service on or after January 1, 2009, will increase the value of the solar credits for residential system owners in particular, and are likely - in conjunction with state, local, and utility rebate programs targeting solar - to spur significant growth in residential, commercial, and utility-scale photovoltaic (PV) installations in the years ahead.

This article ${ }^{1}$ focuses specifically on the residential credit, describing three areas in which removal of the $\$ 2,000$ cap on the residential ITC will have significant implications for PV rebate program administrators, PV system owners, and the PV industry.

\section{1) State, Local, and Utility PV Programs Can Potentially Reduce the Size of the Rebates They Provide Without Negatively Impacting the Market}

With the exception of the smallest systems, which have not been impacted by the $\$ 2,000$ cap on the residential ITC, most residential PV systems installed starting in 2009 will realize significant additional value from the elimination of the ITC cap. State, local, and utility PV program administrators may, in turn, wish to ratchet down the size of the rebates they offer, in order to stretch fixed program budgets and avoid over-stimulating the market. Indeed, at least three major PV programs have already reduced their incentive levels for residential PV as a result of the ITC cap removal, and others are considering the same.

Assuming that residential rebates in 2008 (i.e., prior to the elimination of the ITC cap) were set at a level that provides the desired amount of support to the residential sector, Figure 1 shows the maximum amount by which these rebate levels could - in theory - be reduced (starting in 2009, once the ITC cap is gone) without leaving system owners any worse off on an after-tax basis than they are now under current rebate levels and the \$2,000 ITC cap. Note that Figure 1 assumes that rebates are non-taxable, which is the case if the rebate is provided through a "utility program" (see the original report for a discussion of what constitutes a "utility program"). This tax distinction is important because, if the rebates are considered to be federally-taxable income, then a rebate recipient can claim the $30 \%$ ITC on the full cost (or "tax credit basis") of the system. If, however, the rebates are not taxable income, then the rebate recipient must reduce, by the amount of the rebate, the tax credit basis to which the federal ITC applies. The magnitudes shown in Figure 1 would, therefore, be somewhat larger if taxable rebates were assumed.

For non-taxable rebates, the magnitude of the potential rebate reduction depends only on the starting rebate level as well as the size and cost of the system (Figure 1 assumes that per-unit installed costs decline along a concave curve from $\$ 10.50 / \mathrm{W}$ at $0.5 \mathrm{~kW}$ to $\$ 7.75 / \mathrm{W}$ at $10 \mathrm{~kW}$ ). As shown, small systems $(0.5 \mathrm{~kW}-2 \mathrm{~kW})$ cannot withstand as much of a rebate reduction as can larger systems, because smaller

\footnotetext{
${ }^{1}$ This article is adapted from a longer Berkeley Lab report titled "Shaking Up the Residential PV Market: Implications of Recent Changes to the ITC" and available at http://eetd.lbl.gov/EA/EMP/cases/res-itc-report.pdf. This work was funded by the Clean Energy States Alliance, and by the U.S. Department of Energy (the Office of Energy Efficiency and Renewable Energy, Solar Energy Technologies Program, as well as the Office of Electricity Delivery and Energy Reliability, Permitting, Siting and Analysis) under Contract No. DE-AC02-05CH11231.
} 
systems will benefit less from the removal of the $\$ 2,000$ cap (i.e., they were not as impacted by the cap in the first place). Above roughly $3 \mathrm{~kW}$, however, the curves more or less level out, revealing that a rebate currently set at $\$ 1 / \mathrm{W}$ could be reduced by as much as $\$ 2.5 / \mathrm{W}$ (in theory, going negative) without leaving the system owner any worse off on an after-tax basis. Meanwhile, starting with a non-taxable rebate of $\$ 4 / \mathrm{W}$, the size of the potential reduction is smaller, at roughly $\$ 1.25 / \mathrm{W}$. Falling in between these two extremes are starting rebate levels of $\$ 2 / \mathrm{W}$ and $\$ 3 / \mathrm{W}$. This rank-ordering makes intuitive sense: a small non-taxable rebate reduces the project's "tax credit basis" by less than does a large non-taxable rebate, which means that the removal of the $\$ 2,000$ ITC cap provides greater benefit to a system receiving a smaller non-taxable rebate. Such a system can, in theory, therefore withstand a larger reduction in the size of the rebate.

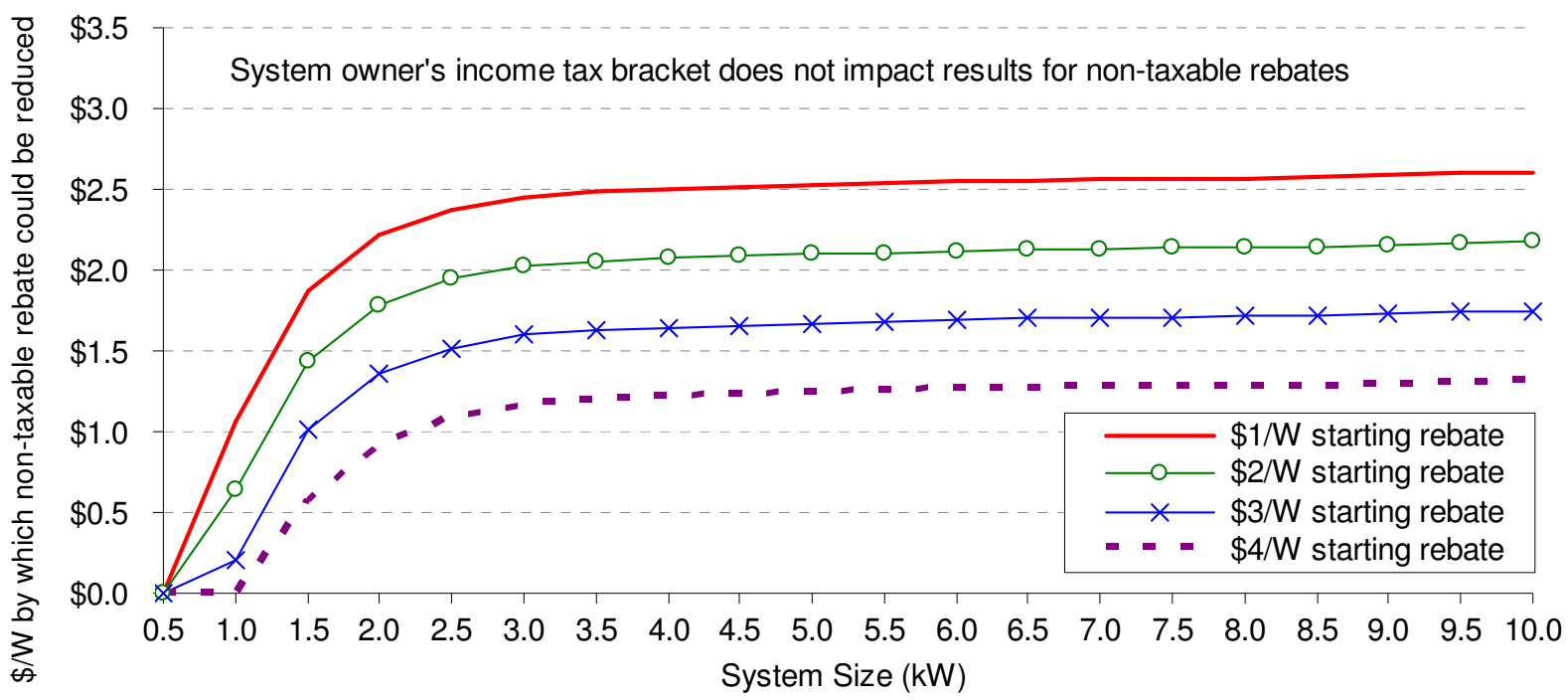

Figure 1. The Maximum Amount By Which A Non-Taxable Rebate Can Be Reduced In Response To The Removal Of The \$2,000 Cap On The Residential ITC

While the idea of shifting part of the cost of supporting residential PV to the federal government must look quite appealing to many utility, state, and local PV program managers, there are, nevertheless, several factors that program managers may wish to consider when deciding whether or by how much to reduce residential rebate levels. These considerations include the following:

- PV system owners may have to wait up to a year or more (depending on how early in the year the system is installed) before they file their yearly tax returns and realize the benefit of the ITC. During this waiting period, the accrued dollar benefit of the ITC must effectively be financed by some other means, which renders the ITC less-useful than an equivalent up-front cash rebate. In this light, it is worth noting that the idea of temporarily (i.e., for projects completed in 2009 and 2010 only) giving taxpayers a choice between the existing ITC or a cash grant of equivalent value (to be disbursed within 60 days of project completion) has been included in an early version of the much-anticipated "stimulus bill" currently being debated by Congress.

- With the $\$ 2,000$ cap removed, the uncapped ITC may be too large for some taxpayers to absorb in the first year, or perhaps ever (in the most extreme cases). Although any unused portion of the credit can be rolled forward at least through 2016, doing so reduces the value of the credit in current dollars. Again, the grant program proposed in an early version of the stimulus bill (and described in the previous bullet) would address this issue, as would a "refundable" ITC, which has also been discussed (i.e., if the taxpayer cannot make use of some or all of the credit in the year it is generated, the government would refund the difference via a cash payment). 
- In recent years, the PV market in the U.S. has been increasingly dominated by the commercial sector. Maintaining the status quo on residential rebate levels, or reducing them by less than is possible, may help to restore more of a balance between the residential and commercial markets.

- Somewhat related, Figure 1 assumes that current rebate levels are set at the "correct" level to provide the desired amount of support to the residential sector. If, instead, current residential rebate levels are too low to adequately stimulate desired market demand, then the results shown in Figure 1 may be too aggressive.

- Finally, leaving residential rebate levels unchanged should accelerate the adoption of residential PV at no extra per-system cost to the program. This motivation, however, must be weighed against the foregone benefit of any additional installations that could be supported by reducing rebate levels and thereby stretching fixed program budgets further.

\section{2) Subsidized Loan Programs May No Longer Make Sense for Many Residential PV Owners}

A number of state and local government agencies offer low-interest loan programs to help finance the installation of PV systems. Although these programs can ease the burden of purchasing a PV system, if the Internal Revenue Service considers such a loan to be "subsidized energy financing," then the 30\% ITC will only apply to the portion of installed project costs not financed by the loan.

With the residential ITC capped at just $\$ 2,000$, the reduction or loss of the ITC due to the use of subsidized energy financing has - up to this point - not necessarily been a losing proposition. Depending on the specifics of the program, attractive financing terms may actually outweigh the loss of the capped ITC. This is particularly true for larger residential PV systems, where the capped ITC represents a smaller proportion of the overall costs that need to be financed.

Now that the cap has been lifted, however, much more economic value is at stake. A $4 \mathrm{~kW}$ system installed at $\$ 8.5 / \mathrm{W}$ and receiving a $\$ 3 / \mathrm{W}$ rebate will now be eligible for an ITC of either $\$ 10,200$ or $\$ 6,600$, depending on whether or not the rebate is taxable. The loss of this amount of tax credit value (or some fraction thereof, if only a portion or the system is financed through such a program) will obviously impinge upon system economics much more so than the loss of just $\$ 2,000$, and will likely make even the most-aggressive low-interest loan programs uneconomical.

Although low-interest loan programs may continue to fill an important need for those residents who are unable to make efficient use of the uncapped ITC regardless, it is now more important than ever to understand whether such programs are at risk of being considered "subsidized energy financing," and to take steps to minimize the potential for such a characterization. Finally, it is worth noting that an early version of the stimulus bill currently being debated by Congress eliminates this "anti-double-dipping" provision altogether, which (if ultimately signed into law) would allow projects to benefit from both subsidized financing and the ITC without any of the negative consequences described above.

\section{3) Third-Party Ownership Structures Now Hold Less Economic Appeal In The Residential Sector}

For several years now, the non-residential sector in the U.S. has benefited from third-party PV financing structures, including leasing and power purchase agreements (PPAs), that enable site hosts to "go solar" without the associated up-front costs and, in some cases, risks of ownership. By engaging "tax equity" investors with an appetite for tax credits, these third-party ownership structures also enable the efficient use of the substantial tax benefits (including the commercial ITC and accelerated tax depreciation) provided to a commercial PV project.

Because commercial PV projects have historically received greater tax benefits than residential systems, one would think that - other potential benefits aside - the ability to monetize and pass along these greater 
tax benefits would have made the residential sector a particularly attractive market for commercial thirdparty ownership. Yet, due to a combination of heightened credit concerns, larger proportional transaction costs, and a simple need to first gain comfort with the structures in a commercial setting, third-party ownership has been somewhat slower in coming to the residential sector than to the commercial sector.

Within the past year, however, several PV installers have begun to offer third-party leases and PPAs to the residential sector. Just as these offerings have begun to make inroads, however, the elimination of the $\$ 2,000$ residential ITC cap starting in 2009 has removed a major advantage of these third-party ownership structures in the residential sector. Specifically, going forward, commercial and residential systems will be on roughly equal footing from a tax perspective, each receiving net tax benefits equal to about $30 \%$ of installed costs on a present value basis.

The loss of this tax-based arbitrage opportunity, however, does not necessarily sound the death knell for third-party ownership in the residential sector. As discussed earlier, with state and local PV programs reducing their residential rebate levels in response to the ITC revisions, with system owners potentially having to wait up to a year or more to realize the tax benefits of the ITC, and with "subsidized" financing programs potentially no longer making much sense for PV, there are likely to be fewer financing options available to cash-strapped prospective PV owners, potentially creating a greater need for third-party ownership than currently exists. Furthermore, third-party ownership provides other potentially attractive benefits besides tax credit monetization (e.g., no performance risk), which may continue to provide a compelling rationale for third-party ownership of residential PV systems.

At the same time, however, many of the tax equity investors that have traditionally financed these thirdparty-owned projects - i.e., large banks and insurance companies - have withdrawn from the PV market as their need to shelter taxable income has disappeared along with their profits, amidst the global financial crisis. Furthermore, if some of the changes to the ITC proposed in early versions of the stimulus package (and described above) come to fruition - e.g., making the credit refundable, or exchanging it altogether for a cash grant of equivalent value - then the need for third-party ownership in the residential sector will likely diminish further.

\section{Conclusions}

Although policy support for emerging technologies generally seeks to reward early adopters, in the case of the residential ITC, procrastinators have been the beneficiaries - initially in 2006 when the capped ITC was first implemented, again in October 2008 when the $\$ 2,000$ cap was eventually lifted (starting in 2009), and perhaps once again in 2009 as a result of the impending stimulus package (remains to be seen). Though welcomed by the industry and prospective PV owners, these changes in federal tax policy have necessitated reactive planning at the state and local levels.

This article has highlighted three ways in which state, local, and utility PV program administrators must remain nimble in responding to the recent changes in federal solar policy:

- Most obviously, program managers may wish to reduce their rebate levels to at least partially compensate for the more-valuable ITC.

- Complementary low-interest loan programs that can be characterized as "subsidized energy financing" may no longer make sense for residential PV (pending the outcome of the stimulus bill being debated by Congress), and should potentially be re-tooled (to focus on providing "unsubsidized" support) or re-directed at other clean technologies for which subsidized energy financing is not as large of an issue. 
- At the same time, third-party financing and ownership models that have recently begun to make inroads into the residential sector may now face a somewhat harder sell. Thus, there may be a continuing need for policies that address financial barriers and support innovative financing models. 